KONSTRUKTIVISME, Vol. 10, No. 1, Januari 2018

p-ISSN: 1979-9438; e-ISSN: 2442-2355

FKIP Universitas Islam Balitar, Blitar

Http://konstruktivisme.unisbablitar.ejournal.web.id; Email: konunisba@gmail.com

\title{
PENGORGANISASIAN SUPERVISI PEMBELAJARAN BERBASIS TIM \\ PARTISIPATIP DI SEKOLAH MENENGAH PERTAMA: STUDI MULTI SITUS DI 3 SEKOLAH MENENGAH PERTAMA DI KOTA BLITAR
}

\author{
Supriyono \\ Prodi Pendidikan Bahasa Inggris FKIP Universitas Islam Balitar Blitar \\ Jl. Majapahit No. 04 Blitar \\ E-mail : supriyono@unisbablitar.ac.id
}

ABSTRAK:

Riset ini mengungkapkan pengorganisasian supervisi pembelajaran berbasis tim partisipatif di tiga sekolah menengah pertama di Blitar, Jawa Timur, Indonesia, Riset ini menggunakan studi multisitus dengan rancangan analisis interaktif dan induksi ubahan. Data dikumpulkan dengan cara interview, observasi, dan dokumentasi. Pengecekan keabsahan dilakukan dengan mengecek derajad kredibilitas, ketergantungan, konfirmabilitas, dan transferabilitas. Riset ini menemukan adanya supevisi pembelajaran dilakukan oleh pengawas dari dinas pendidikan, kepala sekolah, wakil kepala sekolah, dan guru senior dalam mana tanggung jawab dan tanggung gugat dalam supervisi berada pada kepala sekolah. Riset ini berkesimpulan bahwa: (1) berdasarkan peran supervisor dimana kepela sekolah sebagai penanggung jawab supervisi dan dibantu oleh pengawas sekolah, wakil kerpala sekolah, dan guru senior, pengorganisasian supervisi ini dapat meningkatkan hasil supervisi, kompetensi guru, dan kinerja guru, dan (2) berdasarkan alur kerjanya baik pada perencanaan maupun pelaksanaan, pengorganisasian supervisi ini dapat meingkatkan hasil supervisi, kompetensi guru, dan kinerja guru, mengembangkan kemampuan kepemimpinan, ketrampilan administratif, dan memecahkan masalah pembelajaran. Disarankan bahwa riset ini ditindak lanjuti dengan Riset dan Pengenbangan untuk menciptakan model yang kuat yang bisa digunakan secara publik.

Kata kunci: supervisi pembelajaran, pengorganisasian, partisipasi, sekolah menengah 
Supriyono. 2018. Pengorganisasian Supervisi Pembelajaran Berbasis Tim Partisipatip di Sekolah Menengah Pertama: Studi Multi Situs di 3 Sekolah Menengah Pertama di Kota Blitar.

Konstruktivisme, 10 (1): 130-142

\section{ABSTRACT:}

This research was aimed at uncovering the organization of participative team based supervision at three public middle schools in Blitar, East Java, Indonesia. This rersearch used multisite case study with interactive model of analysis combined with modified analytic induction. Data were collected by interview, observation, and documentattion. Credibility, dependability, confirmability, and transferability were checked. Results of this research showed that the instructional supervision was done by superntendent of district education and culture, principals, vise principles, and senior teachers where the principals were the main responsible and accountable supervisors. This risearch concluded that (1) Based on the roles where principals were the principals were the responsible and accountable supervisor assisted by superintendent, vice principals, and teachers, the supervision tended to enhanced the teachers' competency and performance, and (2) Based on the workflow both on the planning and executing, the supervision can enhance the teachers' competency and performance, develop leadership capability, administration skills, and solve instructional problem. It has been suggested to be research by Reasearch and Development to provide model that is usable widely at middle schools.

Keywords: instructional supervision, organization, participation, middle school.

\section{PENDAHULUAN}

Supervisi pembelajaran merupakan bagianyang tidak terpisahkan dari pengembangan profesional guru berkelanjutan (Imron, 2011; Masaong, 2013; Mardiyah, Yurizal, dan Usman, 2014; Herwanti, 2014; Damayanti, 2016; Suwartini, 2017; Supriyono, Imron, Arifin, and Kusmintardjo, 2016, Supriyono, 2017). Supervisi pembelajaran merupakan rangkaian bantuan pelayanan profesional kepada guru (Depdikbud, 1985), yang dapat meningkatkan mutu pendidikan dan profesionalitas guru. Suwartini (2017) menemukan bahwa supervisi akademik yang profesional oleh kepala sekolah secara bersamasama dapat meningkatkan mutu pendidikan dan profesionalitas guru. Selain itu, supervisi pembelajaran diperlukan karena tidak semua guru yang direkrut menjadi guru baru sudah memiliki kesiapan profesional sebagai guru (Imron:2011). Dengan supervisi kebutuhan profesional guru dapat diidenntifikasi dan pengembangan guru dapat dilaksanakan. Supervisi 
Supriyono. 2018. Pengorganisasian Supervisi Pembelajaran Berbasis Tim Partisipatip di

Sekolah Menengah Pertama: Studi Multi Situs di 3 Sekolah Menengah Pertama di Kota Blitar.

Konstruktivisme, 10 (1): 130-142

berfungsi sebagai 1) penelitian, (2) perbaikan, (3) pembinaan, (4) pengembangan, (5) koordinasi, (6) memotivasi, dan (7) penilaian (Masaong, 2013).

Persoalan-persoalan mendasar yang sangat penting untuk mendapat perhatian adalah adanya supervisi sebagai formalitas administratif, supervisor kurang memahami bidang studi sehingga fokusnya adalah administratif, an adanya keluhan atas perlunya keterlibatan guru. Beaver (2002) menemukan bahwa dalam supervisi, kepala sekolah belum menguasai mata pelajaran dan para guru membutuhkan supervisor yang menguasai mata pelajaran. Gentry (2002) juga menemukan hal yang serupa bahwa kepala sekolah kurang ahli dalam lintas mata pelajaran. Paynes (2010) menemukan adanya keperluan pengikutsertaan guru dalam semua aspek supervisi pembelajaran dengan berkolaborasi terus menerus bersama administrator. Sayangnya terdapat kepala sekolah yang masih menjalankan supervisi sebagai formalitas administrasi dan mewakilkan pelaksanaan supervisi kepada wakil kepala sekolah (Damayanti, 2016).

Pada dasarnya merupakan tanggung jawab utama dari kepala sekolah. Namun demikian, keterlibatan wakil kepala sekolah dan guru secara sistemik dapat membantu keberhasilan tujuan supervisi. Zepeda (2007:12) telah mengindikasikan adanya keterlibatan guru dalam supervisi pada tataran peer coaching dan pembelajaran berkelompok. Bays (2001) menemukan adanya peran guru dalam supervisi sebagai mentor guru baru. Mardhiah, Yusrizal, Usman (2014) menemukan adanya supervisi yang secara perencanaannya melibatkan musyawarah dengan guru dan dalam pelaksanaannya dilakukan dengan melibatkan wakil kepala sekolah. Hasil-hasil supervisi pada konteks tersebut rata-rata dapat meningkatkan profesionalitas guru.

Supriyono (2017) menemukan model supervisi pembelajaran yang melibatkan pengawas sekolah, kepala sekolah, wakil kepala sekolah, dan guru secara sistemik. Dikarenakan adanya supervisor yang bukan hanya kepala sekolah, maka fokus pengorganisasian para supervisor dalam konteks peran dan alur kerja serta hubungannya terhadap kompetensi dan kinerja guru men jadi menarik untuk dipelajari. Penelitian ini merupakan bagian dari penelitian Supervisi Pembelajaran di Sekolah Menengah Pertama yang dilaksanakan pada kurun waktu 2012 s/d 2016. Dari proposisi-proposisi yang dihasilkan, penelitian Supriyono (2017) dapat disimpulkan bahwa sinergi kepala sekolah dan pengawas sekolah dalam peran masing masing dan alur kerjanya pada supervisi pembelajaran dapat meningkatkan hasil supervisi 
Supriyono. 2018. Pengorganisasian Supervisi Pembelajaran Berbasis Tim Partisipatip di Sekolah Menengah Pertama: Studi Multi Situs di 3 Sekolah Menengah Pertama di Kota Blitar.

Konstruktivisme, 10 (1): 130-142

yang lebih baik, kompetensi guru, dan kinerja guru. Begitu juga berprtisipasinya wakil kepala sekolah dan guru dalam perannya untuk membantu kepala sekolah secara sistemik menampakkan bahwa hasil supervisi lebih baik dan kompetensi serta kinerja guru meningkat. Pada konteks alur kerjanya, proses supervisi pembelajaran juga menampakkan adanya peningkatan pengembangan kepemimpinan bagi wakil kepala sekolah dan guru, peningkatan ketrampilan administratif, pemecahan masalah pembelajaran, dan hasi belajar yag lebih baik.

Mempelajari hasil penelitian ini, penulis berpendapat bahwa model pengorganisasian supervisi pembelajaran tim patisipatif ini dapat dilaksanakan secara luas di sekolah-sekolah. Sesuai dengan observasi penulis di lapangan pada saat ini, sekolah-sekolah yang diteliti tersebut telah berganti kepala sekolah dan sebagian guru sebagai informen telah berpindah, untuk itulah maka peneliti melakukan penilitian replikasi dengan melibatkan informen yang berbeda untuk mengungkapkan apakah pengorganisasian supervisi pembelajaran berbasis tim partisipatif ini konsisten menghasilkan temuan yang berontribusi terhadap hasil supervisi yang lebih baik, peningkatan kompetensi dan kinerja guru, pemecahan masalah pembelajaran, dan peningkatan hasil belajar. Penelitian replikasi telah menjadi penelitian yang biasa dipakai dalam kalangan imiah sebagaiana dikatakan oleh Bonett (2012:411) sebagai berikut:

Replication-extension studies combine results from prior studies with results from a new study specifically designed to replicate and exted the results of the prior studies. Replication-extension studies have many advantages over the traditional single-study designs used in psychogy: Formal assessments of replication can be obtained, effect sizes can be estimated with greater precision and generalizability, misleading findings from prior studies can be exposed, and moderator effects can be assessed.

Fokus penelitian ini adalah bagaimanakah supervisi pembelajaran di Sekolah Menengah Pertama diorganisasikan dalam konteks peran dan alur kerjanya. Tujuan dari penelitian ni adalah untuk mengungkapkan pengorganisasian supervisi pembelajaran di Sekolah Menengah Pertama dalam konreks peran dan alur kerjanya. 
Supriyono. 2018. Pengorganisasian Supervisi Pembelajaran Berbasis Tim Partisipatip di Sekolah Menengah Pertama: Studi Multi Situs di 3 Sekolah Menengah Pertama di Kota Blitar.

Konstruktivisme, 10 (1): 130-142

\section{METODE}

Riset ini menggunakan penndekatan kualitatif dengan rancangan studi multisitus (Bogdan dan Biklen, 1992), yang tidak mengkouantifikasi data akan tetapi mengugkapkan fenomena secara natural (Bogdan dan Biklen, 1982; Marshall dan Rosman, 1995) dan peneliti sebagai instrumen utama. Data dikumpulkan dengan interview, observasi, dan dokumentasi dan dianalisis secara interaktif (Miles dan Huberman, 1992) serta dilakukan anaisis induksi ubahan (Bogdan dan Biklen, 1982).

Dalam pengumpulan data periset menggunakan catatan lapangan, sekdul interview, perekaman, dokumen, dan ringkasan kontak. Observasi dilakukan secara deskriptif, selektif, dan terfokus. Interview dilakukan secara interview mendalam dan memakai teknik probing. Hasil observasi, interview dan dokumen dimasukkan dalam ringkasan kontak setelah dilakukan reduksi data sebagaimana disarankan oleh Miles and Huberman (1992). Samples diambil dengan cara purposive sampling dengan snow balling techniques. Informan kunci adalah pengawas sekolah, kepala sekolah, wakil kepala sekolah, dan guru senior. Keabsahan data dicek dengan menggunakan pengecekan kredibilitas, depeendabilitas, konfirmabilitas, dan transferabilitas dengan metode triangulasi baik triangulasi sumber dan metode, member check, diskusi kolegial, dan audit yang melibatkan Dr. Sasongko dan Dr. Soim. Kehadiran peneliti dalam riset ini sangat diutamakan,

Pengembangan teori menggunakan metode analisis induksi ubahan dikerjakan dengan (1) menganalisis hasil penelitian sebelumnya, mereview teori dan membangun protokol riset, (2) melakukan riset dan menemukan hasil pada situs pertama, melakukan riset dan menemukan hasil pada situs kedua, dan melakukan induksi hasil riset situs pertama dan kedua, (3) Selanjutnya periset melakukan riset pada situs ke 3 dan menginduksi hasil analisis lintas situs pertama dan kedua ke situs ke tiga, (4) Kemudian periset melakukan perbandingan dan mengungkapkan makna hasil akhirnya, sementara sisi perbedaan tetap dituliskan. Situs penelitian adalah sama dengan peneitian sebelumnya (Supriyono, 2017a,b) dengan informen yang berbeda dan dilakukan pada kurun waktu September 2017 s/d Januari 2018. 
Supriyono. 2018. Pengorganisasian Supervisi Pembelajaran Berbasis Tim Partisipatip di Sekolah Menengah Pertama: Studi Multi Situs di 3 Sekolah Menengah Pertama di Kota Blitar.

Konstruktivisme, 10 (1): 130-142

\section{HASIL}

Riset ini berfokus pada pengungkapan makna 2 (dua) hal, yaitu pengorganisasian supervisi pembelajaran berbasis tim partisipatif dalam koteks peran dan alur kerja. Hasil analisis lintas situsSitus 1 (pertama) dan 2 (kedua), dan 3 (ketiga) pada konteks peran menunjukkan adanya fenomena sebagai berikut:

\begin{tabular}{|c|c|}
\hline Fakta X & Fakta Y \\
\hline $\begin{array}{l}\text { 1. Pengawas sekolah berperan } \\
\text { sebagai supervisor manajerial } \\
\text { dan akademik. Sebagai } \\
\text { supervisor manajerial } \\
\text { mensupervisi kepala sekolah dan } \\
\text { sebagai supervisor akademik } \\
\text { (pembelajaran)bersinergi dengan } \\
\text { kepala sekolah mensupervisi } \\
\text { guru }\end{array}$ & $\begin{array}{l}\text { 1. Capaian hasil supervisi baik } \\
\text { pada tingkat sekolah } \\
\text { maupun dinas lebih baik, } \\
\text { 2. Kompetensi guru meningkat } \\
\text { 3. Menyelesaikan masalah } \\
\text { pembelajaran sesuai mata } \\
\text { pelajaran } \\
\text { 4. Hasil belajar meningkat } \\
\text { 5. Kemampuan kepemimpinan } \\
\text { wakil kepala sekolah dan } \\
\text { guru senior meningkat }\end{array}$ \\
\hline $\begin{array}{l}\text { 2. Kepala sekolah berperan sebagai } \\
\text { supervisor manajerial untuk } \\
\text { keseluruhan operasional } \\
\text { pendidikan dan supervisor } \\
\text { akademik (pembelajaran) untuk } \\
\text { pembelajaran dan dibantu oleh } \\
\text { wakil kepala sekolah dan guru } \\
\text { senior. }\end{array}$ & $\begin{array}{l}\text { Ketrampilan administratif } \\
\text { wakil kepala sekolah, guru } \\
\text { senior, dan guru meningkat. }\end{array}$ \\
\hline $\begin{array}{l}\text { 3. Wakilkepala sekolah berperan } \\
\text { sebagai supervisor akademik } \\
\text { (pembelajaran) dan atas } \\
\text { penugasan dari kepala sekolah } \\
\text { membantu kepala sekolah untuk }\end{array}$ & \\
\hline
\end{tabular}


Supriyono. 2018. Pengorganisasian Supervisi Pembelajaran Berbasis Tim Partisipatip di Sekolah Menengah Pertama: Studi Multi Situs di 3 Sekolah Menengah Pertama di Kota Blitar.

Konstruktivisme, 10 (1): 130-142

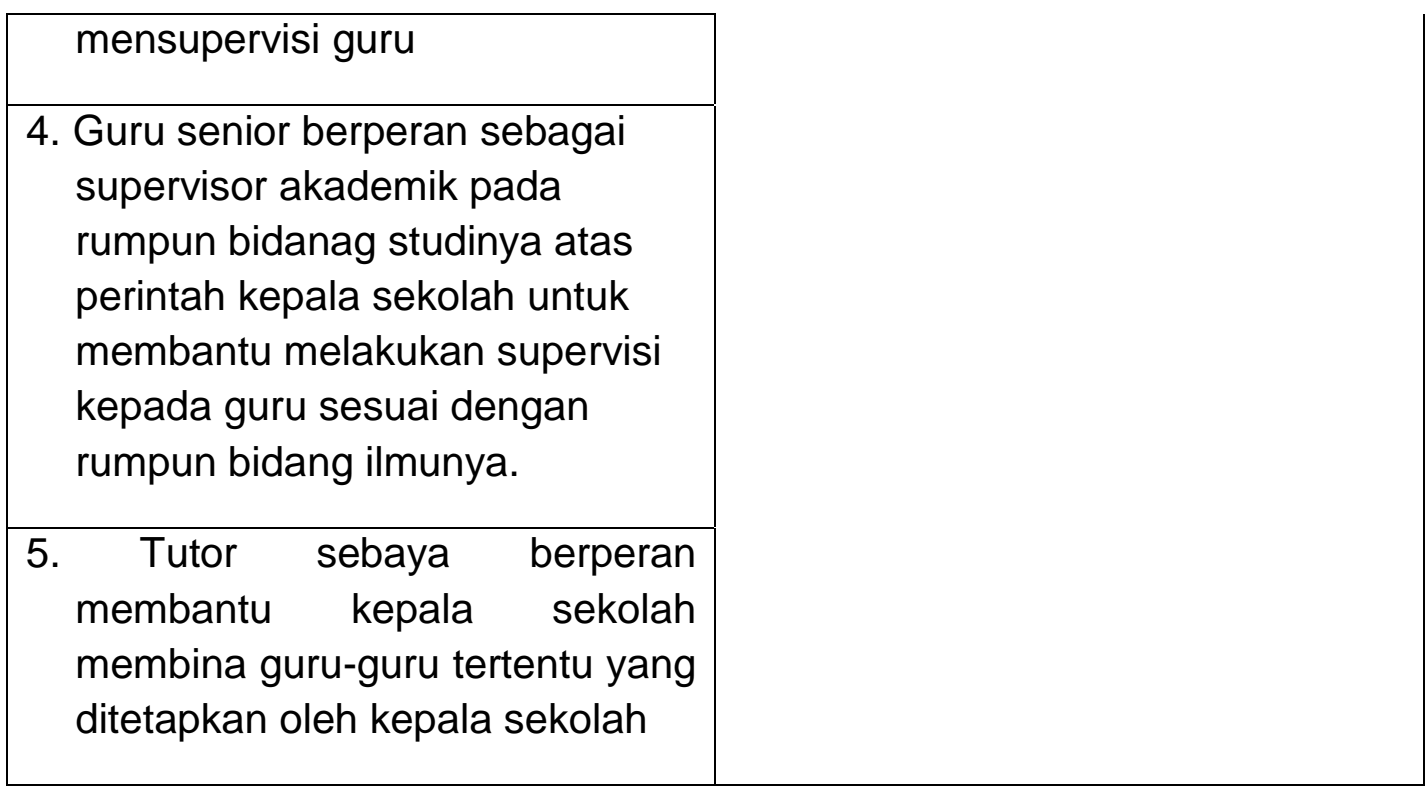

Hasil tersebut dapat dimaknai dalam model substantif sebagai berkut:

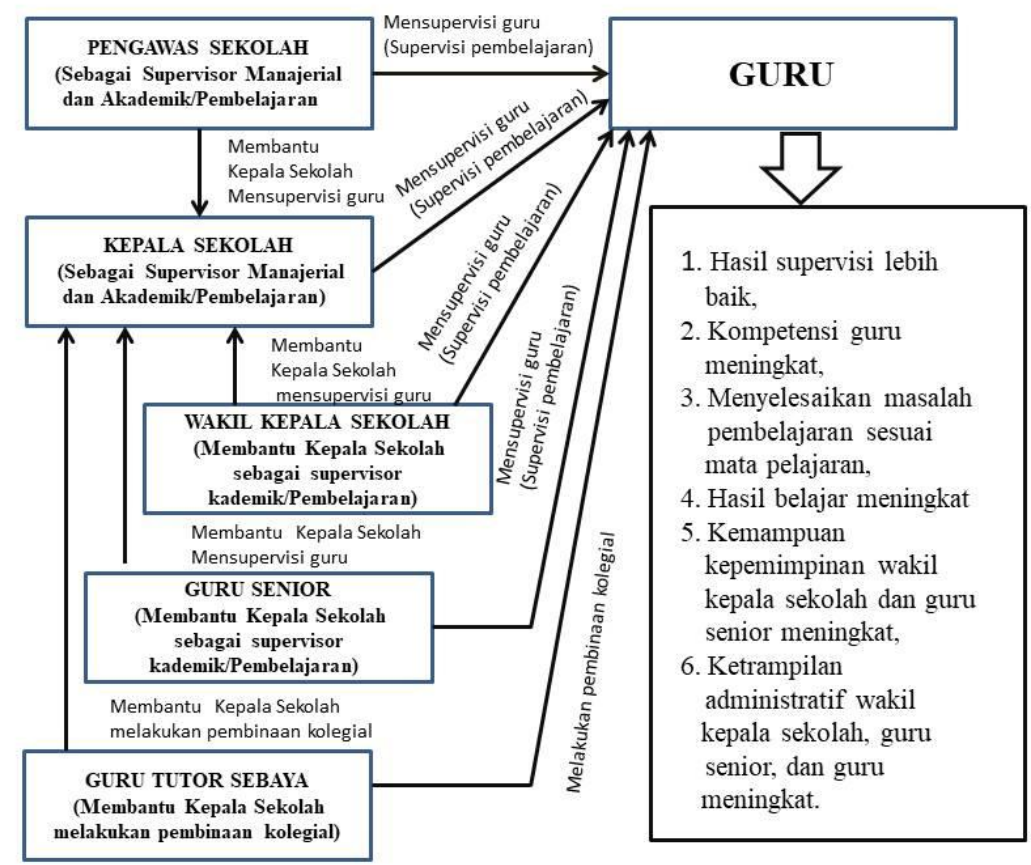

Gambar 1: Peran Supervisor dalam pengorganisasian supervisi pembelajaran berbasis Tim Partisipatif 
Supriyono. 2018. Pengorganisasian Supervisi Pembelajaran Berbasis Tim Partisipatip di Sekolah Menengah Pertama: Studi Multi Situs di 3 Sekolah Menengah Pertama di Kota Blitar.

Konstruktivisme, 10 (1): 130-142

Hasil nalisis lintas situs pada situs 1 (satu), 2 (dua), dan 3 (tiga) pada konteks alur kerja menunjukkan adanya fenomea sebagai berikut:

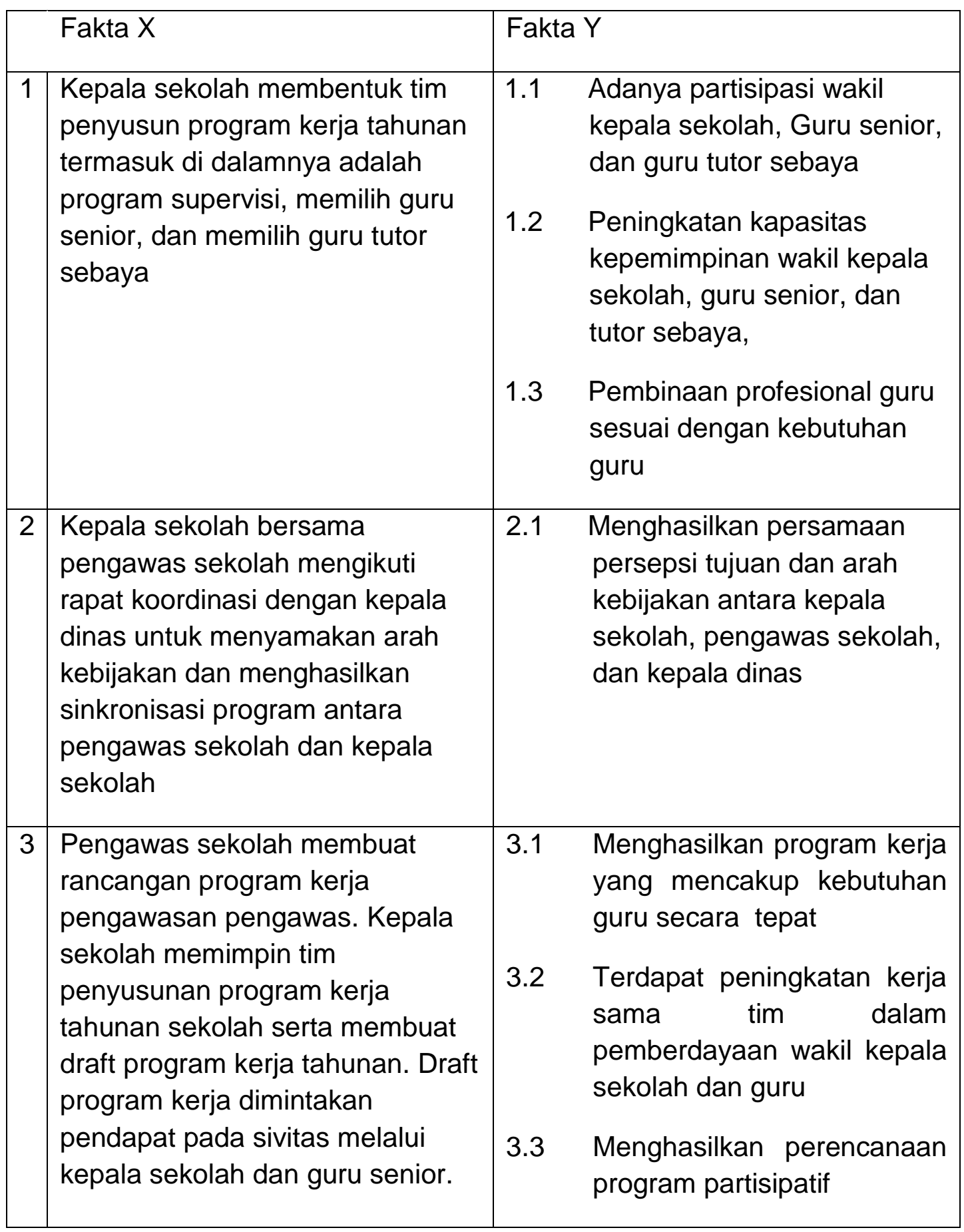


Supriyono. 2018. Pengorganisasian Supervisi Pembelajaran Berbasis Tim Partisipatip di Sekolah Menengah Pertama: Studi Multi Situs di 3 Sekolah Menengah Pertama di Kota Blitar.

Konstruktivisme, 10 (1): 130-142

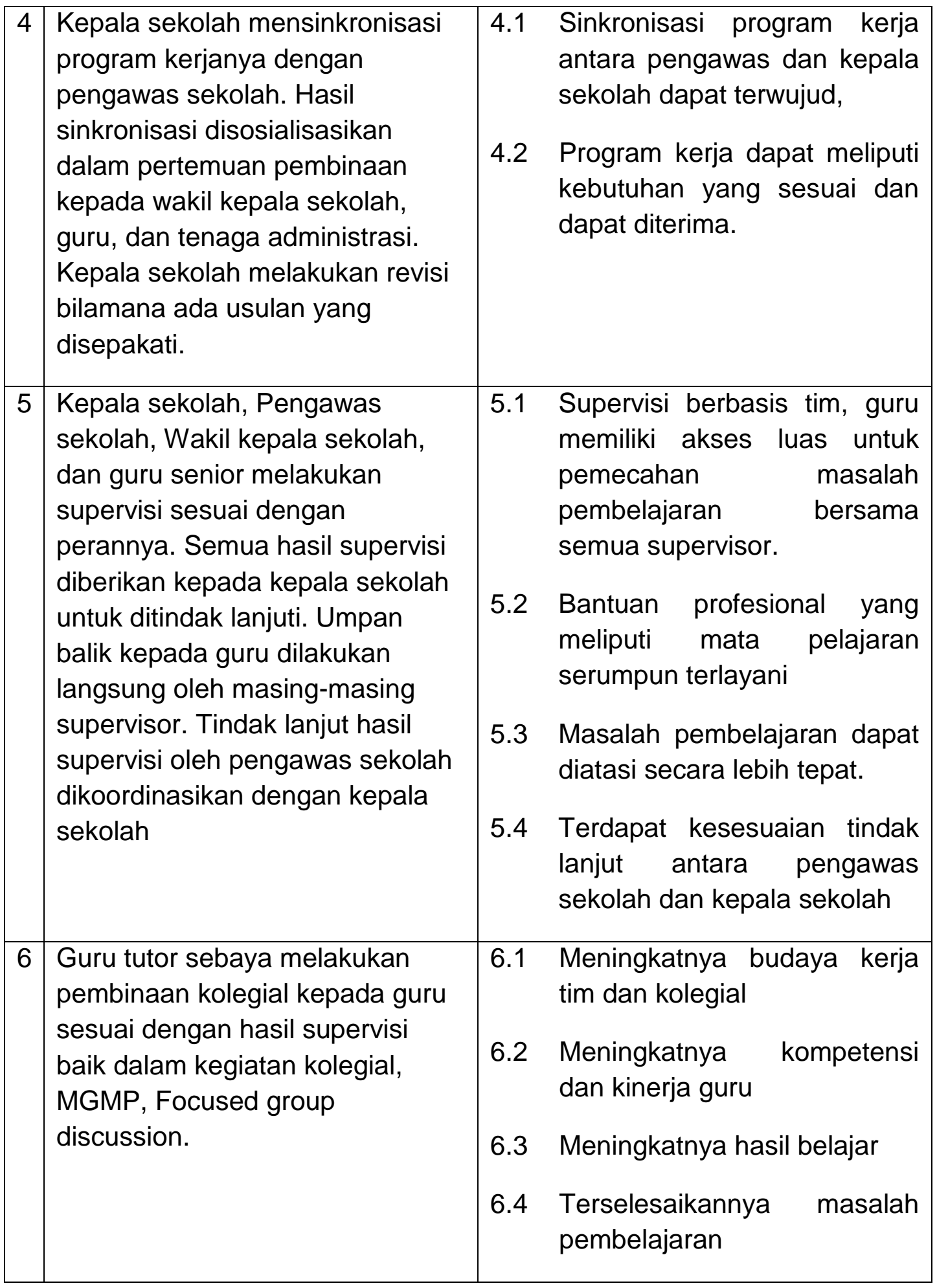


Supriyono. 2018. Pengorganisasian Supervisi Pembelajaran Berbasis Tim Partisipatip di Sekolah Menengah Pertama: Studi Multi Situs di 3 Sekolah Menengah Pertama di Kota Blitar.

Konstruktivisme, 10 (1): 130-142

1. Kepala sekolah membentuk tim penyusun program kerja tahunan termasuk di dalamnya adalah program supervisi, memilih guru senior, dan memilih guru tutor sebaya

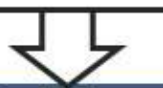

2. Kepala sekolah bersama pengawas sekolah mengikuti rapat koordinasi dengan kepala dinas untuk menyamakan arah kebijakan dan menghasilkan sinkronisasi program antara pengawas sekolah dan kepala sekolah

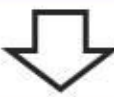

3. Pengawas sekolah membuat rancangan program kerja pengawasan pengawas. Kepala sekolah memimpin tim penyusunan program kerja tahunan sekolah serta membuat draft program kerja tahunan. Draft program kerja dimintakan pendapat pada sivitas melalui kepala sekolah dan guru senior.

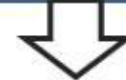

4. Kepala sekolah mensinkronisasi program kerjanya dengan pengawas sekolah. Hasil sinkronisasi disosialisasikan dalam pertemuan pembinaan kepada wakil kepala sekolah, guru, dan tenaga administrasi. Kepala sekolah melakukan revisi bilamana ada usulan yang disepakati.
5. Kepala sekolah, Pengawas sekolah, Wakil kepala sekolah, dan guru senior melakukan supervisi sesuai dengan perannya. Semua hasil supervisi diberikan kepada kepala sekolah untuk ditindak lanjuti. Umpan balik kepada guru dilakukan langsung oleh masingmasing supervisor. Tindak lanjut hasil supervisi oleh pengawas sekolah dikoordinasikan dengan kepala sekolah

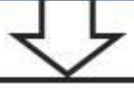

6. Guru tutor sebaya melakukan pembinaan kolegial kepada guru sesuai dengan hasil supervisi baik dalam kegiatan kolegial, MGMP focused group discussion.

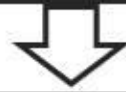

HASIL

1. Sinkronisasi program kerja

2. Kesesuaian pengembangan profesional guru dengan kebutuhan

3. Meningkatnya buaya kerja tim dan kolegial

4. Meningkatnya kompetensi dan kinerja guru

5. Meningkatya penyelesaian masalah pembelajaran

6. Meningkatnya kapasitas kepemimpinan

7. Meningkatnya ketrampilan administratif

8. Terwujudnya partisipasi sivitas dalam program supervisi

\section{Gambar 2: Model Substantif pengorganisasian supervisi pembelajaran berbasis tim partisipatif.}


Supriyono. 2018. Pengorganisasian Supervisi Pembelajaran Berbasis Tim Partisipatip di Sekolah Menengah Pertama: Studi Multi Situs di 3 Sekolah Menengah Pertama di Kota Blitar.

Konstruktivisme, 10 (1): 130-142

Dari hasil tersebut dapatlah disusun proposisi-proposisi sebagai berikut:

\section{Proposisi peran}

a) Jika kepala sekolah bersinergi dengan pengawas sekolah baik di dalam perencanaan maupun pelaksanaan supervisi pembelajaran, maka capaian hasil supervisi baik di tingkat sekolah dan dinas lebih baik, kompetensi guru meningkat, kinerja guru meningkat, dan hasil pembelajaran meningkat.

b) Jika wakil kepala sekolah dan guru senior berperan membantu kepala sekolah dalam supervisi pembelajaran, maka capaian hasil supervisi baik di tingkat sekolah dan dinas lebih baik, kompetensi guru meningkat, kinerja guru meningkat, masaah pembelajaran dapat diatasi dengan tepat, dan hasil pembelajaran meningkat.

c) Jika guru tutor sebaya berperan untuk membina guru secara kolegial, maka permasalahan guru dalam pembelajaran bisa diatasi, kompetensi guru meningkat, kinerja guru meningkat, dan hasil pembelajaran meningkat.

\section{Proposisi alur kerja}

a) Jika alur kerja proses supervisi pembelajaran dalam perencanaannya melibatka pengawas sekolah, kepala sekolah, wakil kepala sekolah, guru senior, dan partisipasi guru, maka terjadi kesesuaian arah kebijakan program baik pada dibas maupun sekolah dengan kebutuhan guru sehingga program supervisi sebagai pengembangan profesional guru dan pemecahan masalah tepat sasaran.

b) Jika alur kerja proses supervisi pembelajaran yang dalam pelaksanaannya melibatkan pengawas sekolah, kepala sekolah, wakil kepala sekolah, dan guru senior dengan membuka saran guru, umpan balik yang konstruktif, dan tindak lanjut yang tepat, maka kemampuan kepemimpinan wakil kepala sekolah dan guru senior meningkat, kompetensi dan kinerja guru meningkat, masalah pembelajaran teratasi dengan tepat, dan hasil belajar siswa meningkat.

\section{BAHASAN}

Hasilriset ini menunjukkan adanya konsistensi hasil dengan riset disertasi Supriyono (2017), yang artinya bahwa model supervisi pembelajaran yang melibatkan tim partisipatif dalam konteks pengorganisasiannya secara konsisten menunjukkan adanya hubungan yang positip antara peran dan alur kerja supervisors dengan pemecahan masalah pembelajaran, peningkatan 
Supriyono. 2018. Pengorganisasian Supervisi Pembelajaran Berbasis Tim Partisipatip di

Sekolah Menengah Pertama: Studi Multi Situs di 3 Sekolah Menengah Pertama di Kota Blitar.

Konstruktivisme, 10 (1): 130-142

kompetensi guru, peningkatan kinerja guru, dan peningkatan hasil belajar siswa.

Hasil riset ini menjawab permasalahan perlunya keterlibatan guru di dalam supervisi pembelajaran dan perlunya mengatasi masalah penguasaan mata pelajaran yang kurang dikuasai kepala sekolah secara lintas bidang studi, sebagaimana ditemukan oleh Beaver (2002), Gentry (2002), dan Paynes (2010). Ketiganya menemukan adanya fakta bahwa kepala sekolah kurang menguasai mata pelajaran lintas bidang studi dan guru perlu dilibatkan di dalam supervisi. Hasil riset ini juga memberikan jawaban atas temuan Damayanti (2016) yang mengungkap bahwa kepala sekolah masih menjalankan supervisi sebagai formalitas administrasi dan mewakilkan pelaksanaannya kepada wakil kepala sekolah.

Hasil penelitian ini mendukung Zepeda (2007), Bays (2001), dan Mardhiah, Yusrizal, Usman (2014) yang menemukan adanya keterlibatan guru dalam supervisi pada tataran peer coaching dan pembelajaran berkelompok, peran sebagai mentor guru baru dan dalam perencanaan supervisi secara musyawarah, serta keterlibatan wakil kepala sekolah yang rata-rata menghasilkan peningkatan profesionalitas guru.

\section{SIMPULAN}

Dari hasil tersebut dapatlah disimpulkan bahwa:

1. Pengorganisasian peran supervisor yang menempatkan kepala sekolah sebagai penanggung jawab (responsible) dan penanggung gugat (accountable) supervisi pembelajaran dan menempatkan pengawas sekolah, wakil kepala sekolah, guru senior, dan tutor sebaya dapat meningkatkan capaian hasil supervisi baik di sekolah dan dinas, pemecahaan masalah pembeajaran, kompetensi dan kinerja guru, peningkatan kapasitas kepemimpinann guru senior dan wakil kepala sekolah, dan peningkatan hasil belajar siswa,

2. Alur kerja proses supervisi pembelajaran yang melibatkan pengawas sekolah, kepala sekolah, wakil kepala sekolah, guru senior, dan guru tutor sebaya dengan konsistensi peran setiap supervisor baik dalam perencanaan, pelaksanaan, dan evaluasi dapat meningkatkan kemampuan kepemimpinan wakil kepala sekolah dan guru senior meningkat, kompetensi dan kinerja guru meningkat, masalah pembelajaran teratasi dengan tepat, dan hasil belajar siswa meningkat. 
Supriyono. 2018. Pengorganisasian Supervisi Pembelajaran Berbasis Tim Partisipatip di Sekolah Menengah Pertama: Studi Multi Situs di 3 Sekolah Menengah Pertama di Kota Blitar.

Konstruktivisme, 10 (1): 130-142

\section{SARAN}

Hasil penelitian ini menunjukkan bahwa pelibatan wakil kepala sekolah da guru secara sistemik dalam supervisi pembelajaran memberikan hasil yang konstruktif untuk pemecahan masalah pembelajaran, peningkatan kompetensi guru, peningkatan kinerja guru, dan hasil belajar siswa.Variabel keberhasilan lainnya adalah peningkatan kemampuan kepemimpinan wakil kepala sekolah dan guru senior serta keterlibatan pengawas sekolah juga menampakkan adanya peningkatan hasil capaian supervisi baik di sekolah dan di dinas pendidikan. Berdasarkan konnsideran ini, periset mengajukan saran untuk digunakannya model ini secara meluas. Agar penggunaan secara meluas tersebut benar-benar dapat terpercaya, maka periset menyarankan adanya riset lanjutan berupa riset kuantitatif atau Riset dan Pengembangan.

\section{DAFTAR RUJUKAN}

Bays, D.A. 2002. Supervision of Special Education Instruction in Rural Public School Districs: A Grounded Theory. Unpublished Dissertation. Blaksburg, Virgina: Virgina Polytechnic Institute and State University

Beaver, D.M. 2002.Instructional Supervision:Perspectives of Middle School Fine Arts Teachers. Unpublished Dissertation. Athens, Georgia: The University of Georgea

Bogdan, R.C. dan Biklen, S.K. 1982. Qualitative Research for Education: An Introduction to Theory and Methods. London: Allyn and Bacon, Inc.

Bogdan, R.C. dan Biklen, S.K., 1998. Qualitative Research for Education: An Introduction to Theory and Methods. London: Allyn and Bacon, Inc

Marshall, C. \& Rossman, G.B. 1995.Designing Qualitative Research.Second Edition. London: Sage Publication, Inc

Bonett, D.G.2012. Replication-Extension Studies.Current Direction in Psychological Science, 21(6) 409-412,

DOI:10.1177/0963721412459512. http://cdps.sagepub.com

Gentry, SR, G.C., 2002. A Case Study of The Issues High School Principals

Encouter with Instructional Supervision. Unpublished

Dissertation.Georgia:Georgia University

Damayanti, W. 2016. Peningkatan Mutu Kinerja Guru Melalui Supervisi Akademik di SMK Negeri 1 Salatiga Menghadapi PKG 2016 (Solusi Perubahan dengan Gabungan Model Supervisi Akademik Artistic Model dan Cooperative Development Model). Jurnal Pendidikan IImu Sosial, Vol 26, No.1, Juni 2016, ISSN: 1412-3835 
Supriyono. 2018. Pengorganisasian Supervisi Pembelajaran Berbasis Tim Partisipatip di

Sekolah Menengah Pertama: Studi Multi Situs di 3 Sekolah Menengah Pertama di Kota Blitar.

Konstruktivisme, 10 (1): 130-142

Miles H.B. and Huberman, A.M.1992.Qualitative Data Analysis : A Sourcebook

of New Methods.6th Ed.Baverley Hill, CA: Sage Publication, Inc

Masaong, A.K. 2013.Supervisi Pembelajaran dan Pengembangan Kapasitas

Guru.Memberdayakan Pengawas Sebagai Gurunya Guru. Bandung:

Penerbit Alpabeta

Mardiyah, A, Yurizal, dan Usman, N. 2014. Peningkatan Profesionalitas Guru

Melalui Supervisi Akademik Di SMP Negeri 3 Peusangan, Kabupaten

Bireuen.Jurnal Administrasi Pendidikan, ISSN 2302-0156Pascasarjana

Universitas Syiah Kuala, 1 - Volume 4, No. 2, November 2014, p 1-11

Herwanti, K. 2014. Model Supervisi Pengajaran Kimia SMA Berbasis

Kompetensi Profesional (SPK-SMA-BKP).Prosiding Seminar Nasional

Sains dan Pendidikan Sains IX, Fakultas Sains dan Matematika, UKSW

Salatiga, 21 Juni 2014, Vol 5, No 1, ISSN: 2087-0922

Imron, A.2011. Supervisi Pembelajaran Tingkat Satuan Pendidikan. Jakarta:

Bumi Aksara

Paynes, E.T.2010. Implementing Wlaktrhoughs: One School's Journey.

Unpublished Dissertation. Falls Church, VA: Virginia Polytechnic

Institute abd State University

Suwartini, E.A. 2017. Supervisi Akademik Kepala Sekolah, Profesionalisme Guru

dan Mutu Pendidikan. Jurnal Administrasi Pendidikan Vol.XXIV No.2

Oktober 2017

Supriyono, Imron, A., Arifin, I. and Kusmintardjo.2016. Ingegrated participative team based instructional supervision management at middle schools in

Blitar, East Java, Indonesia: A Multisite study. Journal of Social

Sciences.htttp://centreofexcellence.nnet/J/JSS\%20mainpage.htm

Supriyono.2017.Supervisi Pembelajaran Di Sekolah Menengah Pertama

(Studi Multisitus pada SMPN 1, SMPN 2, dan SMPN4 Kota Blitar.Disertasi tidak dipublikasikan.Malang: Pasca Sarjana Universitas Malang

Zepeda, S.J.2007. Instructional Supervision: Applying Tools and Concepts.

Larchmont, NY:Eye on Education, Inc 